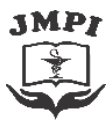

Jurnal Mandala Pharmacon Indonesia, Vol 5.No.1 Juni 2019

Avaiable online at www.jurnal-pharmaconmw.com/jmpi

$p$-ISSN : 2442-6032

$e$-ISSN : 2598-9979

\title{
Analisis Kepuasan Pasien Terhadap Pelayanan Kefarmasian Di Rumah Sakit Dan Apotek
}

\author{
Rahmawati Raising ${ }^{1}$, Susanti Erikania ${ }^{2}$ \\ ${ }^{1}$ Program Studi S1 Farmasi, Stikes Bhakti Husada Mulia Madiun \\ ${ }^{2}$ Program Studi D3 Farmasi, Stikes Bhakti Husada Mulia Madiun
}

\begin{abstract}
ABSTRAK
Upaya pelayanan kesehatan adalah suatu suatu kegiatan yang terpadu, terintegrasi dan berkesinambungan, yang bertujuan untuk memelihara dan meningkatkan derajat kesehatan masyarakat dalam mencegah terjadinya penyakit, peningkatan kesehatan, pengobatan penyakit, dan pemulihan kesehatan. Mutu pelayanan kesehatan adalah dimana pelayanan kesehatan yang dapat menimbulkan kepuasan pada pasien untuk mengukur kualitas pelayanan kesehatan. Tujuan penelitian adalah untuk mengetahui tingkat kepuasan pasien terhadap pelayanan kefarmasian di Rumah Sakit (RS) dan di Apotek serta analisis perbandingan tingkat kepuasan. Pada kualitas jasa untuk melihat kepuasan pasien terdapat lima dimensi, yaitu meliputi Kehandalan (reliability), Ketanggapan (responsiveness), Jaminan (assurance), Empati (empathy) dan Bukti Langsung (tangible), sehingga masalah yang mendasari penelitian ini adalah seberapa besar perbandingan tingkat kepuasan di RS dan Apotek berdasarkan kelima dimensi ini. Penelitian ini merupakan jenis penelitian deskriptif dengan pendekatan cross sectional. Data diperoleh dari kuesioner yang dibagikan kepada subjek peneliti dengan tujuan untuk mengetahui kepuasan dari
\end{abstract}

masing-masing 200 pasien pada pelayanan kefarmasian di Rumah Sakit dan di Apotek, Teknik pengambilan sampel adalah dengan menggunakan Non Probability Sampling, menggunakan metode accidental sampling. Hasil kuisioner yang telah dinilai skala persentase kepuasan responden, dimana pada dimensi kehandalan RS 75\% Apotek 78\%, Ketanggapan RS 68\% Apotek $76 \%$, Jaminan RS 63 \% Apotek 72\%, Empati RS 74\% Apotek 69\%, Bukti langsung RS 69\% Apotek 61\%. ke 5 dimensi termasuk dalam kategori puas (61\%-80\%) dan perbandingan analisis kepuasan pasien terhadap pelayanan kefarmasian di RS dan Apotek dengan menggunakan spss adalah tidak terdapat perbedaan yang bermakna dari kelima dimensi (>0.05).

Kata kunci : Kepuasan Pasien, Pelayanan Kefarmasian, Rumah Sakit, Apotek

\section{Penulis Korespondensi :}

Rahmawati Raising 1

Program Studi S1 Farmasi, Stikes Bhakti Husada Mulia Madiun

E-mail :Rahmawati.raising@gmail.com

\section{PENDAHULUAN}

Kesehatan merupakan salah satu kebutuhan dasar manusia, kesehatan sendiri tidak dapat terlepas upaya pelayanan kesehatan dan sarana pelayanan kesehatan Upaya pelayanan kesehatan dapat diartikan sebagai suatu rangkaian kegiatan yang dilakukan secara terpadu, terintegrasi dan berkesinambungan, yang bertujuan antara lain untuk memelihara dan meningkatkan derajat kesehatan masyarakat. Hal ini dapat dilaksanakan dalam bentuk pencegahan penyakit, peningkatan kesehatan, pengobatan penyakit, dan pemulihan kesehatan (preventif, promotif, kuratif dan rehabilitatif) (Atta NS., dkk., 2016).

Mutu pelayanan pada bidang kesehatan adalah pelayanan kesehatan yang menimbulkan kepuasan pada pasiem. Kepuasan menjadi bagian penting dalam pelayanan kesehatan karena dapat mengukur kualitas pelayanan kesehatan (Novaryatiin, 2018). Konsumen atau 
pasien apabila merasa puas dengan jasa pelayanan yang diteriman oleh mereka akan memperlihatkan kecenderungan yang besar untuk menggunakan kembali jasa tersebut dimasa yang akan datang (Prabandari, 2017).

Tujuan penelitian adalah untuk mengetahui kepuasan pasien terhadap pelayanan kefarmasian di Rumah Sakit dan di Apotek serta analisis perbandingan tingkat kepuasan.

Pada dimensi kualitas jasa untuk melihat kepuasan pasien dardapat lima dimensi, yaitu meliputi Kehandalan (reliability), Ketanggapan (responsiveness), Jaminan (assurance), Empati (empathy) dan Bukti Langsung (tangible) (Novaryatiin, 2018). sehingga masalah yang mendasari penelitian ini adalah seberapa besar perbandingan tingkat kepuasan di RS dan Apotek berdasarkan kelima dimensi ini.

Standar pelayanan kefarmasian adalah tolak ukur yang digunakan sebagai pedoman bagi tenaga kefarmasian dalam melaksanakan pelayanan kefarmasian yang bertujuan meningkatkan mutu pelayanan kefarmasian, menjamin kepastian hukum bagi tenaga kefarmasian, melindungi pasien dan masyarakat dari penggunaan obat yang tidak rasional dalam rangka keselamatan pasien (patient safety) (Permenkes RI, 2016).

Kepuasan pasien merupakan perasaan senang yang muncul di dalam diri seseorang setelah mendapat pelayanan yang diterima atau dialam secara langsung atau dengan kata lain tingkat perasaan seorang pelanggan setelah membandingkan kinerja atau hasil yang dirasakan (Irine, 2015).

Mutu pelayanan kesehatan adalah pelayanan kesehatan yang dapat menimbulkan kepuasan pada setiap pasien dimana tata cara penyelenggaraannya sesuai dengan standard dan kode etik yang telah ditetapakan. Kepuasan menjadi bagian penting dalam pelayanan kesehatan sebab kepuasan pasien tidak dapat dipisahkan dari kualitas pelayanan kesehatan. Jika ingin melakukan peningkatan kualitas pelayanan maka diperlukannya survei tingkat kepuasan pasien (Novaryatin, 2018).

\section{METODE PENELITIAN}

Penelitian ini merupakan jenis penelitian deskriptif dengan pendekatan cross sectional. Pada penelitian ini, peneliti membagi menjadi dua kelompok yaitu kelompok penilaian kepuasan di Rumah Sakit dan Kelompok di Apotek.

\section{A.Populasi dan Sampel Penelitian}

1. Populasi Penelitian

Populasi penelitian ini adalah seluruh pasien atau keluarga pasien yang menebus obat di Apotek dan Rumah Sakit.

2. Cara pengambilan sampel dan jumlah sampel.

Pengambilan sampel dilakukan dengan cara Non Probability Sampling, menggunakan metode accidental sampling, dengan jumlah sampel sebanyak jumlah subjek yang memenuhi kriteria inklusi. Jumlah besaran sampel minimal ditetapkan dengan rumus sebagai berikut:

$\mathrm{n}=\frac{Z\left(1-\frac{a}{2}\right)^{2} P(1-P)}{d^{2}}$

Keterangan:

$\mathrm{n} \quad=$ jumlah sampel minimal

$Z\left(1-\frac{a}{2}\right)=$ nilai standar normal untuk $\alpha$

$=0,05(1,96)$

$P \quad=$ estimasi proporsi populasi $(P=$ $0,5)$

$\mathrm{d}=$ tingkat kesalahan yang dipilih adalah penyimpangan $10 \%(d=0,1)$

$\mathrm{n}=\frac{Z\left(1-\frac{a}{2}\right)^{2} P(1-P)}{d^{2}}$

$\mathrm{n}=\frac{(1,96)^{2} \times 0,5(1-0,5)}{(0,1)^{2}}$

$\mathrm{n}=\frac{3,84 \times 0,25}{0,01}$

$\mathrm{n}=96$

dari perhitungan didapat jumlah sampel minimal sebanyak 96 responden. 
3. Kriteria Inklusi

a. Responden berumur $\geq 18$ tahun.

b. Responden bisa berkomunikasi, membaca dan menulis dengan baik.

c. Bersedia menjadi responden.

4. Kriteria Eksklusi
a. Responden tidak bisa menggerakkan bagian tubuh dengan baik.
b. Pasien atau keluarga pasien yang menebus obat tidak menggunakan resep

\section{B.Instrumen Penelitian}

Penelitian ini menggunakan kuesioner yang terdiri dari lima dimensi kualitas pelayanan diantaranya reliability, responsiveness, assurance, empathy, dan tangible. Pada masing-masing dimensi pelayanan kefarmasian diberikan beberapa pertanyaan, dimana setiap pertanyaan memiliki skor. Jumlah skor dihitung berdasarkan kategorinya.

Instrumen yang digunakan untuk mengukur variabel penelitian ini dengan menggunakan skala likert 5 poin. Skala likert digunakan untuk mengukur sikap, pendapat dan persepsi seseorang atau sekelompok orang tentang fenomena sosial (Sugiyono, 2014)

Tabel 1. Penilaian Skala Likert

\begin{tabular}{|c|c|}
\hline Penilaian & Skor \\
\hline Sangat Puas & 5 \\
\hline Puas & 4 \\
\hline Cukup Puas & 3 \\
\hline Kurang Puas & $\mathbf{2}$ \\
\hline Tidak Puas & 1 \\
\hline
\end{tabular}

a. Untuk jawaban sangat puas mendapat skor 5

b. Untuk jawaban puas mendapat skor 4

c. Untuk jawaban cukup mendapat skor 3

d. Untuk jawaban kurang puas mendapat skor 2

e. Untuk jawaban tidak puas mendapat skor 1

Penentuan interval range skala kepuasan dengan cara menentukan interval (rentang jarak) dan intepretasi persen (\%) agar dapat mengetahui penilaian dengan metode mencari interval skor persen (I). Rumus interval :

$$
\text { I = Jumlah responden / Jumlah skor (likert) }
$$

\section{Perhitungan :}

$\mathrm{I}=$ Jumlah responden / Jumlah skor (likert)

$\mathrm{I}=100 / 5$

$\mathrm{I}=20$

Hasil (I) $=20$ (Ini adalah intervalnya jarak dari terendah o\% hingga tertinggi 100\%)

Berikut tabel range skala kepuasan responden:

Tabel 2. Range Skala Kepuasan

Responden

\begin{tabular}{|c|c|c|}
\hline No & Penilaian & $\begin{array}{c}\text { Nilai skala } \\
\text { peringkat }\end{array}$ \\
\hline 1 & Sangat Puas & $81 \%-100 \%$ \\
\hline 2 & Puas & $61 \%-80 \%$ \\
\hline 3 & Cukup Puas & $41 \%-60 \%$ \\
\hline 4 & Kurang Puas & $21 \%-40 \%$ \\
\hline 5 & Tidak Puas & $0 \%-20 \%$ \\
\hline
\end{tabular}

(Sumber: Sugiyono, 2010)

Scoring yaitu pemberian nilai/pengukuran kepuasan pasien yang dilakukan dengan cara menghitung presentase masing-masing indikator pertanyaan (responsiveness, reliability, assurance, emphaty dan tangible).

Rumus Index \%:

$$
\%=\frac{\Sigma \text { skor perolehan }}{\Sigma \text { skor maksimum }} \times 100 \%
$$

Keterangan :

$$
\begin{aligned}
& \begin{array}{l}
\sum \text { skor } \\
\text { perolehan }
\end{array}=\begin{array}{l}
\text { Total dari seluruh jawaban } \\
\text { responden pada setiap item }
\end{array} \\
& \underset{\text { maksimum }}{\sum \text { skor }}=\begin{array}{l}
\text { Nilai skala likert tertinggi } \mathrm{x} \\
\text { jumlah responden }
\end{array}
\end{aligned}
$$

\section{HASIL DAN PEMBAHASAN}

Populasi dalam penelitian ini adalah pasien atau keluarga pasien yang menebus obat di Rumah Sakit dan Apotek dengan jumlah subjek masing-masing 200 responden, dimana terlebih dahulu melakukan pengujian terhadap instrument penelitian untuk mengetahui validitas (ketepatan) dan realibilitas (ketepatan) instrument penelitian. 
Tabel 3 Hasil Karakteristik Pasien

\begin{tabular}{|l|c|c|c|c|c|}
\hline \multicolumn{2}{|c|}{ Karakteristik } & \multicolumn{4}{c|}{ Total Pasien } \\
\cline { 3 - 6 } & & Jumlah (n) & $\begin{array}{c}\text { Persentase } \\
(\%)\end{array}$ & $\begin{array}{c}\text { Jumlah } \\
(\mathrm{n})\end{array}$ & $\begin{array}{c}\text { Persentase } \\
(\%)\end{array}$ \\
\hline \multirow{2}{*}{ Jenis Kelamin } & Laki-Laki & 73 & 36,5 & 102 & 51 \\
\cline { 2 - 6 } & Perempuan & 127 & 63.5 & 98 & 49 \\
\hline Usia & $26-35$ & 24 & 12 & 107 & 53.5 \\
\hline & $36-45$ & 43 & 21.5 & 46 & 23 \\
\hline & $46-55$ & 62 & 31 & 34 & 17 \\
\hline & $56-65$ & 54 & 27 & 9 & 4.5 \\
\hline & $>65$ & 17 & 8.5 & 4 & 2 \\
\hline
\end{tabular}

Dari tabel 3 dapat diketahui bahwa karakteristik pasien berdasarkan jenis kelamin pada pasien rumah Sakit yang berjenis kelamin laki-laki 36.5\% dan perempuan 63.5\%, sedangkan pada Apotek Jenis Kelamin Laki-laki 51\% dan perempuan 49\%. Pada karakteristik usia pada Rumah sakit yang paling banyak usia 36-45 tahun, sedangkan pada apotek yang menebus obat paling banyak diusia 26- 35 tahun.

Tabel 4 Hasil Uji Validasi Kuesioner di Rumah Sakit dan Apotek

\begin{tabular}{|c|c|c|c|}
\hline Pertanyaan (Q) & $\mathbf{r}_{\text {hitung }}$ & $\mathbf{r}_{\text {tabel }}$ & Keterangan \\
\hline \multicolumn{4}{|c|}{ Dimensi Kehandalan } \\
\hline Q1 & 0.493 & 0.361 & Valid \\
\hline Q2 & 0.657 & 0.361 & Valid \\
\hline Q3 & 0.666 & 0.361 & Valid \\
\hline Q4 & 0.409 & 0.361 & Valid \\
\hline Q5 & 0.755 & 0.361 & Valid \\
\hline Q6 & 0.587 & 0.361 & Valid \\
\hline \multicolumn{4}{|c|}{ Dimensi Daya Tanggap } \\
\hline Q7 & 0.596 & 0.361 & Valid \\
\hline Q8 & 0.427 & 0.361 & Valid \\
\hline Q9 & 0.550 & 0.361 & Valid \\
\hline \multicolumn{4}{|c|}{ Dimensi Jaminan } \\
\hline Q10 & 0.459 & 0.361 & Valid \\
\hline \multicolumn{4}{|l|}{ Dimensi Empati } \\
\hline Q11 & 0.604 & 0.361 & Valid \\
\hline Q12 & 0.632 & 0.361 & Valid \\
\hline Q13 & 0.387 & 0.361 & Valid \\
\hline Q14 & 0.658 & 0.361 & Valid \\
\hline Q15 & 0.651 & 0.361 & Valid \\
\hline \multicolumn{4}{|c|}{ Dimensi Bukti Langsung } \\
\hline Q16 & 0.486 & 0.361 & Valid \\
\hline Q17 & 0.558 & 0.361 & Valid \\
\hline Q18 & 0.538 & 0.361 & Valid \\
\hline
\end{tabular}

Dari tabel 4 dapat diketahui bahwa apabila $\mathbf{r}_{\text {hitung }}>\mathbf{r}_{\text {tabel }}$ dengan tingkat kepercayaan 95\% dari tabel uji r, maka pertanyaan tersebut valid. Dalam hal ini, rtabel dengan $\mathrm{n}=30$ dan $\alpha=0,05$ adalah 0,361. Dari hasil uji validitas dapat 
diambil kesimpulan bahwa seluruh pertanyaan pada kuesioner yang telah dibuat peneliti dinyatakan valid.
Metode uji reliabilitas yang digunakan dalam penelitian ini adalah uji reliabilitas Cronbach"s Alpha dengan bantuan program SPSS 20.

Tabel 5.1 Hasil Uji Reliablitas Kuesioner di Rumah Sakit dan Apotek

\begin{tabular}{ccc}
\hline Cronbach's Alpha & Pembanding & Keterangan \\
\hline 0.73 & 0.6 & Reliabel \\
\hline
\end{tabular}

Kuesioner dinyatakan reliable / handal jika Alpha-Cronbach $\geq 0,60$ dan tidak handal jika Alpha-Cronbach < 0,60. Dari tabel 4 dapat diketahui bahwa nilai reliabilitas yaitu $0,73>0,6$ hasil tersebut menyatakan bahwa seluruh dimensi pertanyaan kuesioner reliabel/konsisten.
Dimensi kualitas pelayanan kefarmasian dibagi menjadi 5 yaitu dimensi kehandalan, ketanggapan, jaminan, empati dan bukti langsung. Berikut gambaran kepuasan responden berdasarkan dimensi kualitas pelayanan.

Tabel 5 Gambaran Hasil Persentase Dimensi Kualitas Pelayanan di Rumah Sakit dan di Apotek

\begin{tabular}{cccccc}
\hline Pelayanan Kefarmasian & \multicolumn{2}{c}{ Rumah Sakit } & \multicolumn{2}{c}{ Apotek } \\
\cline { 2 - 5 } & $\begin{array}{c}\text { Hasil Persentase } \\
\text { (\%) }\end{array}$ & Kategori & $\begin{array}{c}\text { Hasil } \\
\text { Persentase } \\
\text { (\%) }\end{array}$ & Kategori & Nilai p \\
\hline Kehandalan & 75 & Puas & 78 & Puas & 0,477 \\
\hline Ketanggapan & 68 & Puas & 76 & Puas & 0,142 \\
\hline Jaminan & 63 & Puas & 72 & Puas & 0,155 \\
\hline Empati & 74 & Puas & 69 & Puas & 0,241 \\
\hline Bukti Langsung & 69 & Puas & 61 & Puas & 0,445 \\
\hline
\end{tabular}

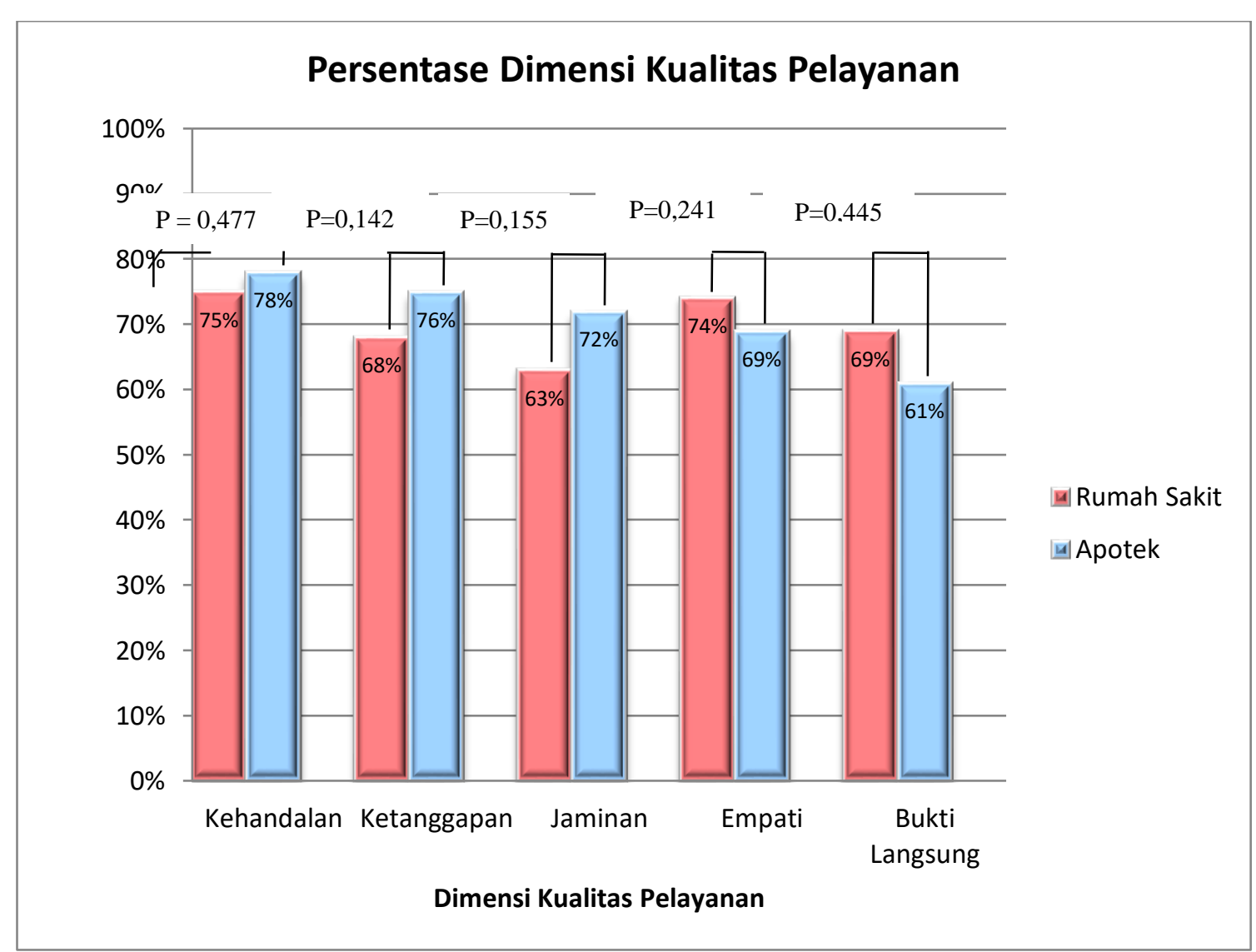

Gambar 5.1 Grafik Hasil Persentase Dimensi Kualitas Pelayanan di Rumah Sakit dan Apotek 
Berdasarkan tabel 5 Hasil kepuasan responden terbagi atas 5 dimensi kualitas pelayanan yaitu dimensi kehandalan, ketanggapan, jaminan, empati dan bukti langsung. Dimana hasil kepuasan responden di Rumah Sakit pada dimensi kehandalan memperoleh persentase sebesar 75\%, dimensi empati memperoleh persentase sebesar 74\%, dimensi bukti langsung memperoleh persentase sebesar 69\%, dimensi ketanggapan memperoleh persentase sebesar $68 \%$, dimensi jaminan memperoleh persentase sebesar $63 \%$, dan dari 5 kategori termasuk dalam kategori puas $(61 \%-80 \%)$.

Hasil kepuasan responden di Apotek pada dimensi kehandalan memperoleh persentase sebesar $78 \%$, dimensi ketanggapan memperoleh persentase sebesar $76 \%$, dimensi jaminan memperoleh persentase $72 \%$, dimensi empati memperoleh persentase sebesar 69\%, dimensi bukti langsung memperoleh persentase sebesar 61\% dan dari 5 kategori termasuk dalam kategori puas (61\% 80\%).

Gambaran Kepuasan Responden Rumah Sakit pada dimensi kehandalan, responden yang merasa puas mencerminkan bahwa petugas kefarmasian terampil dalam melakukan pelayanan secara cepat, teliti dan tepat, namun menurut beberapa responden petugas farmasi jarang bahkan tidak memberikan informasi terkait penggunaan obat. Oleh karenanya, petugas farmasi harus lebih komunikatif kepada pasien. Begitupun responden di Apotek merasa puas karena pemberian informasi obat, dosis obat, cara penyimpanan obat, dan apa yang dilakukan terhadap obat yang tersisa dengan baik dan teliti.

Dimensi ketanggapan dinilai puas oleh responden karena petugas farmasi di Rumah Sakit dan Apotek telah tanggap terhadap masalah pasien dan setiap keluhan pasien diatasi dengan cepat serta akurat.

Dimensi jaminan responden Rumah Sakit dan Apotek merasa puas dikarenakan petugas farmasi terampil dan teliti dalam memberikan pelayanan yang diserahkan serta terjaminnya kualitas.
Namun petugas farmasi harus lebih meningkatkan keterampilan dan ketelitian dalam memberikan informasi obat, sebab informasi yang salah akan menjadi pemicu terjadinya medication error pada pasien.

Dimensi empati di Rumah sakit mendapatkan persentase terendah dengan indikator keramahan petugas saat menyapa pasien, menurut pendapat dari beberapa responden petugas farmasi bersikap kurang begitu ramah dan cenderung tergesa-gesa saat menyampaikan informasi obat. Hal ini sering terjadi saat banyaknya jumlah pasien yang berobat sehingga petugas farmasi lebih terfokus pada pelayanan resep saja, tetapi secara umum pada dimensi ini pasien merasa puas dengan pelayanan yang diberikan seperti kepedulian terhadap keluhan pasien tanpa membedakan status sosial. Berbeda dengan di Apotek responden merasa puas pada dimensi ini karena pelayanan kefarmasian yang ada di Apotek memberi informasi tanpa harus menunggu responden meminta, dan petugas juga bersikap sopan dan ramah dalam memberikan informasi obat.

Dimensi kelima yaitu dimensi bukti langsung, hasil penelitian menunjukkan bahwa di Rumah Sakit dan Apotek responden merasa puas dengan pelayanan dan fasilitas yang didapatkan seperti tersedianya ruang informasi yang nyaman, petugas menuliskan aturan pakai yang mudah dimengerti, namun pihak rumah sakit diharapkan menyediakan informasi kesehatan tambahan bagi pasien seperti brosur/leavlet/artikel tentang cara hidup sehat, pengelolaan obat yang benar DAGUSIBU (Dapatkan, Gunakan, Simpan, Buang) dan lain sebagainya.

Analisis statistik perbedaan kepuasan di Rumah Sakit dan Apotek menggunakan uji uji parametrik $\mathrm{t}$ bebas (independent $\mathrm{t}$ test) $(\mathrm{p}<0,05)$, apabila data tidak terdistribusi normal maka akan dilakuakan uji nonparametrik Mann Whitney ( $p>0,05)$. Perbandingan tingkat kepuasan pasien terhadap pelayanan kefarmasian di Rumah Sakit dan Apotek adalah pada dimensi kehandalan nilai 
signifikan $\mathrm{p}=0,477$, dimensi ketanggapan nilai $\mathrm{p}=0,142$, dimensi jaminan nilai $\mathrm{p}=$ 0,155 , dimensi empati nilai $p=0,241$ dan dimensi bukti langsung nilai $\mathrm{p}=0,445$, dimana tidak terdapat perbedaan yang bermakna dimana dari kelima dimensi.

\section{KESIMPULAN}

Hasil analisis tingkat Kepuasan Pasien Terhadap Pelayanan Kefarmasian di Rumah sakit dapat diambil kesimpulan bahwa Tingkat kepuasan pasien terhadap pelayanan kefarmasian di Rumah Sakit pada dimensi kehandalan $75 \%$, dimensi empati $74 \%$, dimensi bukti langsung $69 \%$, dimensi ketanggapan 68\%, dimensi jaminan 63\%, dan dari 5 kategori termasuk dalam kategori puas.

Tingkat kepuasan pasien terhadap pelayanan Kefarmasian di Apotek pada dimensi kehandalan 78\%, dimensi ketanggapan $76 \%$, dimensi jaminan $72 \%$, dimensi empati 69\%, dimensi bukti langsung $61 \%$ dan dari 5 kategori termasuk dalam kategori puas.

Perbandingan tingkat kepuasan pasien terhadap pelayanan kefarmasian di Rumah Sakit dan Apotek adalah dimana tidak terdapat perbedaan yang bermakna dimana dari kelima dimensi

\section{DAFTAR PUSTAKA}

Atta NS., dkk., 2016., Kekuatan Pembuktian Rekam Medis Konvensional dan Elektronik., Magister Hukum Kesehatan., Universitas Katolik Soegijapranata Semarang.

Irene, 2015. Tingkat Kepuasan Pasien Rawat Jalan Terhadap Kualitas pelayanan di Apotek Instalasi Farmasi Rumah Sakit Umum Daerah Sragen. Surakarta.

Novaryatiin, Susi., dkk. 2018. Tingkat Kepuasan Pasien Terhadap Pelayanan Kefarmasian di RSUD dr. Murjani Sampit. Borneo Jurnal of Pharmacy, Volume I Issue May 2018, Page 22-26. Universitas Muhammadiyah Palangkaraya:Palangkaraya.

Peraturan Menteri Kesehatan RI No. 72 Tahun 2016. Tentang Standar Pelayanan Kefarmasian di Rumah
Sakit. Jakarta: Kementerian

Kesehatan Republik Indonesia Prabandari.S.2017. Gambaran Tingkat Kepuasan Pasien Berdasarkan Pelayanan Informasi Obat di Apotek Nur Bunda Tegal. Tegal.

Sugiyono, 2010. Statistika Untuk Penelitian. Alfabeta, Bandung.

Sugiyono. 2011. Metode Penelitian Kuantitatif Dan Kualitatif. Alfabeta:Bandung.

Sugiyono. 2014. Metodologi Penelitian Pendidikan. Alfabeta:Bandung.

Sugiyono. 2014. Skala Likert Metode Perhitungan, Presentase dan Interval. Alfabeta:Bandung. 